\title{
Basic Industry and Chemicals Subsector Cash Flow Ratios and Profitability
}

\author{
Fanny Soewignyo, Tonny Irianto Soewignyo \\ Universitas Klabat, Airmadidi, Manado, Sulawesi Utara, Indonesia
}

\begin{abstract}
This paper aims to predict profitability using two types of operating cash flow ratio. In a cross sectional study, the authors gathered data from manufacturing companies listed under basic industry and chemicals subsector on Indonesia Stock Exchange in 2013. To be included in the sample, each company must have available all required data for the test period and outliers are determined and removed. Accordingly, from the total population of 60 companies, the final sample contains 40 companies. The authors find that first, greater current cash debt coverage ratio worsens return on assets. Secondly, the greater the cash debt coverage ratio, the higher the return on assets and return on equity. Further, the authors' findings suggest that cash debt coverage ratio has more predictive ability relative to current cash debt coverage ratio on profitability. Surprisingly, it was found that both current cash debt coverage ratio and cash debt coverage ratio have no predictive ability on earnings per share. Overall, the evidence highlights the influence of financial liquidity and financial flexibility on profitability as measured by return on assets and return on equity. This study contributes to current understanding of the usefulness of operating cash flow ratios in predicting profitability.
\end{abstract}

Keywords: cash debt coverage ratio, current cash debt coverage ratio, financial flexibility, financial liquidity, profitability

Cash flow is a very important element for a company's success or failure. Creditors examine the cash flow statement beginning by discovering net cash provided by operating activities. A large amount of this component implies that a company is qualified to generate sufficient cash from operations to pay its obligations without additional borrowing (Kieso, Weygandt, \& Warfield, 2011). This research is concerned with the analysis of operating cash flow based measures to predict profitability of Indonesia's basic industry and chemicals subsector.

Many cash flow ratios were discussed and analyzed in prior studies for evaluating performance (e.g. Ibarra, 2009; Jooste, 2006; Kirkham, 2012). Ibarra (2009) analyzed 16 cash flow ratios as tools for evaluating financial position of the three manufacturing companies in the Philippines for the years 2004 to 2007. Four years' intracompany ratios were analyzed to find out if the ratios can be used to assess company performance. The findings show that cash flow ratios can be used as tools for financial analysis of the manufacturing companies, however, the ratios were not used as predictor variables. A comparative study was conducted by Jooste (2006)

Corresponding author: Fanny Soewignyo, Ph.D. in commerce, assistant professor, Universitas Klabat, Airmadidi, Manado, Sulawesi Utara, Indonesia; research fields: accounting, finance, and corporate performance.

Tonny Irianto Soewignyo, Ph.D. in commerce, associate professor, Universitas Klabat, Airmadidi, Manado, Sulawesi Utara, Indonesia; research fields: entrepreneurial, finance, marketing, and quality management. 
for three years using nine cash flow ratios of chemical, food, and electronic industries. The comparison of the United States of America (USA) and the South Africa (SA) industries reveals some similarities and some differences. Yet, the ratios were used for performance comparison only. Kirkham (2012) compared the traditional liquidity ratios and cash flow ratios of 25 companies from telecommunications sector in Australia. The traditional ratios comprised of current ratio, quick ratio, and interest coverage ratio. From the statement of cash flows, the ratios are current cash debt coverage ratio, critical needs cash coverage, and cash interest coverage. The study provides evidence of the importance of cash flow ratios compared to the tradional liquidity ratios. The analysis shows the usefulness of the cash flow ratios in investigating companies' financial statements. Still, the cash flow ratios were not used as predictor to company performance.

Most previous studies seem to agree that cash flow information is important in predicting company performance. However, to the authors' knowledge, there has been no research conducted by utilizing the two cash flow ratios (current cash debt coverage ratio and cash debt coverage ratio) as introduced by Kieso et al. (2011) to predict company profitability. Previous studies (see for example, Bee \& Abdollahi, 2013; Bhandari \& Iyer, 2013; Rujoub, Cook, \& Hay, 1995) emphasize the importance of cash flow ratios to predict business failures. Akbar, Shah, and Stark (2011) investigated the value relevance of cash flow measure, however, the cash flow component is computed as cash flow from operating activities, less net interest paid, less taxes paid, and plus research and development. The results suggest that cash flows can have incremental value relevance relative to either earnings or funds flows.

This study is unique in many respects. First, the sample companies are manufacturing listed under basic industry and chemicals subsector on Indonesia Stock Exchange. Manufacturing industry is the largest contributors to Indonesian GDP due to the employment opportunities (Public Communication Center Ministry of Industry Republic of Indonesia, 2012). This industry represents an attractive option to foreign as well as domestic investors. Second, the two-predictor variables used were operating cash flow ratios to measure financial liquidity and flexibility. According to Strong (2007), the figures of cash flow from operations are generally applied by security analysts as analytical tool to assess company's earnings quality and subsequently to estimate future dividend and earnings growth. Furhermore, market valuation is more a function of cash flow than earnings. Third, Amuzu (2010) asserted that cash flow ratios to predict company performance are gradually attaining prominence. This paper intends to contribute to this insight by evaluating the usefulness of cash flow ratios to predict profitability of manufacturing companies listed under basic industry and chemicals subsector on Indonesia Stock Exchange in 2013.

The remainder of this paper is organized as follows. The next section reviews the extant literature on the subject and the testable hypotheses are then developed. The research method is presented in third section followed by the empirical results and disccussion, while section five concludes the paper.

\section{Literature Review and Testable Hypotheses}

\section{Cash Flow}

From the three sections of statement of cash flow, creditors will first analyze net cash flow from operating activities. A large amount of net cash flow from operating activities indicates that a company is able to generate sufficient positive cash from operations to pay its obligation (Kieso et al., 2011). Furthermore, it indicates that the company can maintain and grow its operations. On the contrary, negative or small amount of net cash flow from operations indicates that the company should seek external financing. As explained by Subramanyam and 
Wild (2009), it is cash that repays the obligations, replaces fixed assets, expands facilities, and pays dividends. Consequently, analyzing cash flow helps in evaluating financial liquidity, solvency, and flexibility. For that reason, this study considers the figures derived from cash flow from operating activities section to determine financial liquidity measured by current cash debt coverage ratio and financial flexibility measured by cash debt coverage ratio.

(1) Current Cash Debt Coverage Ratio (CCDCR). Cash flow ratios provide a more wholistic approach to the analysis of companies' liquidity position (Kirkham, 2012). CCDCR introduced by Kieso et al. (2011) is used in this study to evaluate the liquidity of a company. This ratio is included in the study of Ibarra (2009) to evaluate companies' financial position; the study of Kirkham (2012) to be compared to the traditional liquidity ratio; and the study of Bhandari and Iyer (2013) to predict firm's failure. Subramanyam and Wild (2009) asserted that liquidity is the proximity to cash and liabilities. CCDCR indicates the ablity of a company to pay its current liabilities from operations. Besides, according to D'Amato (2010), this ratio provides more understandable result compared to the traditional liquidity ratio, since it reveals the degree of how short-term obligation is met by the cash generated from operations. The higher this ratio, the lower the level of risk.

(2) Cash Debt Coverage Ratio (CDCR). This ratio is used to measure financial flexibility of a company that indicates company's ability to settle its liabilities as they come due using cash provided by operating activities. It reveals whether the company can still survive without external sources of funds (Kieso et al., 2011). The higher the ratio is, the more financial flexibility the company has and the less likely the company will experience financial problems in the future (Mills \& Yamamura, 1998). Moreover, financial flexibility indicates the capability of a company to respond and adjust to opportunities and difficulties (Subramanyam \& Wild, 2009). Ibarra (2009) analyzed CDCR as one of the 16 tools to evaluate manufacturing companies' financial position, whilst Jooste (2006) used this ratio as one of the operating cash flow ratios to compare USA and SA industries performance.

\section{Profitability}

The main source of poor company performance according to the study of Keramidou, Mimis, Fotinopoulou, and Tassis (2013) is primarily due to the low profitability. Profitability ratios as stated by Subramanyam and Wild (2009) serve to evaluate the periodic financial success or failure of a company. Therefore, this study employed three profitability ratios (rate of return on assets, rate of return on equity, and earnings per share) to evaluate company performance.

(1) Rate of Return on Assets (ROA) measures overall profitability of a company's assets and is computed by dividing net income by average total assets (Weygandt, Kimmel, \& Kieso, 2013). It indicates how efficient a company utilized its assets to generate earnings (Khatab, Masood, Zaman, Saleem, \& Saeed, 2011). This is the most effective measure to assess company performance by examining income statement performance and company assets to run the business. It denotes the fundamentals of company performance. This rate involves many noncurrent asset decisions that are more difficult to be interfered within the short-term period (Hagel III, Brown, Samoylova, \& Lui, 2013).

(2) Rate of Return on Equity (ROE) measures the rate of income earned on the amount invested by shareholders. It is used to assess the profitability of the investment by shareholders (Reeve, Warren, \& Duchac, 2012) and is calculated as net income/average total shareholder's equity. de Wet and du Toit (2007) stated that this rate is a popular financial performance measure to assess shareholders' wealth. 
(3) Earnings per Share (EPS) is a financial measure that is generally used to evaluate company performance in a given year. Investors have used this measure as an indicator to assess the stewardship and performance of company directors and managers (Jerris, n.d.). EPS measures the net income earned on each ordinary share and is computed by dividing net income available to ordinary shareholders by the number of weighted-average ordinary shares outstanding for a given year. It provides a useful view to verify profitability (Weygandt et al., 2013). The net income to compute EPS is derived from earnings after interest, depreciation, and tax. Stock brokers and investors make use of EPS in making decision about the market value of the equity share of a company (Bhatt \& Sumangala, 2012).

\section{The Importance of Cash Flow Ratios in Predicting Profitability}

Numerous authors agree on the significance of cash flow for financial analysis. This study focuses on cash flow from operations in measuring financial liquidity and flexibility. According to Jooste (2006), cash flow from operations is important to assess company performance. A significant positive relationship of operating cash flows to corporate performance has been documented by Frank and James (2014). They examined the relationship between cash flow and company performance using six food and beverages companies listed on Nigerian Stock Exchange for the period of 2007 to 2011 to determine the interrelationships between cash flows and corporate performance. They find a significant positive relationship between operating cash flows and company performance. The increase in operating cash flows leads to increase in profits.

By utilizing liquidity measures such as current ratio and cash gap of Saudi companies, prior study of Eljelly (2004) revealed a significant negative relationship between liquidity and profitability. The results implied that although a certain level of liquidity level is desired, it could cause lost profits as a result of holding excessive liquidity. The losses could be decreased by implementing efficient liquidity management strategies. Eyisi and Okpe (2014) employed cash to debt ratio by dividing cash flow from operations by total debt and critical needs ratio by dividing cash flow from operations - interest divided by interest + current debt + dividends to measure financial liquidity. The result indicates that cash basis liquidity ratio is a better indicator to measure corporate performance. This ratio offers a better insight on liquidity position of the company and provides as an important tool for predicting business failure. The study emphasizes the application of cash flow ratio as a better indicator for assessing company performance.

Concerning the impact of financial flexibility on the investment and performance of East Asian companies, Ayaydin, Florackis, and Ozkan (2014) found that financial flexibility is an important indicator of performance during the Asian crisis of 1997-1998. However, during the global financial crisis of 2007-2009, the result suggests that financial flexibility towards investing persists but is significantly less pronounced during that period. The study of Meier, Bozec, and Laurin (2013) showed that low levels of financial flexibility earned low returns during the financial crisis, and on the other hand, firms with very high level of financial flexibility did not perform very well either. At the same time, the study shows that financial flexibility has value.

In the light of the theoretical and empirical discussions, the authors expect the following hypotheses:

$\mathrm{H}_{1}$ : The higher the level of financial liquidity measured by current cash debt coverage ratio (CCDCR), the better the profitability (ROA, ROE, EPS);

$\mathrm{H}_{2}$ : The higher the level of financial flexibility measured by cash debt coverage ratio (CDCR), the better the profitability (ROA, ROE, EPS). 


\section{Research Method}

In a cross sectional study, the authors gathered data from manufacturing companies listed under basic industry and chemicals subsector on Indonesia Stock Exchange in 2013. To be included in the sample, each company must have available all required data for the test period and outliers are determined and removed. Accordingly, from the total population of 60 companies, the final sample contains 40 companies. Graphical plots showed that there is no major concern about linearity assumptions. The variance inflation factors (VIF) indicate that multicollinearity is not a problem, and no heteroskedasticity caused by the variables. To examine the predictive ability of the two operating cash flow ratios to profitability, the following multiple regression models are established:

$$
\begin{aligned}
& \mathrm{ROA}=\beta_{0}+\beta_{1} \mathrm{CCDCR}+\beta_{2} \mathrm{CDCR}+\varepsilon(\text { model } 1) \\
& \mathrm{ROE}=\beta_{0}+\beta_{1} \mathrm{CCDCR}+\beta_{2} \mathrm{CDCR}+\varepsilon(\text { model } 2) \\
& \mathrm{EPS}=\beta_{0}+\beta_{1} \mathrm{CCDCR}+\beta_{2} \mathrm{CDCR}+\varepsilon(\text { model } 3)
\end{aligned}
$$

The regression models (1-3) are estimated separately for the total sample. Table 1 shows the variables used in the study.

Table 1

Variables and Their Proxy Measure Determination

\begin{tabular}{llc}
\hline Notation & Description & Measurement \\
\hline ROA & Rate of return on assets & $\begin{array}{c}\text { Net income } \\
\text { Average total assets } \\
\text { Net income }\end{array}$ \\
EPS & Rate of return on equity & $\begin{array}{c}\text { Average total stockholders' equity } \\
\text { Net income - preference dividends }\end{array}$ \\
CCDCR & Earnings per share & Current cash debt coverage ratio \\
CDCR & Cash debt coverage ratio & $\frac{\text { Net cash provided by operating activities }}{\text { Average current liabilities }}$ \\
\hline
\end{tabular}

\section{Empirical Results and Discussion}

Table 2 presents the results of multiple regression analysis. The first regression model of the study with ROA as dependent variable shows that the calculated value of F-statistic is 10.065 and the significant $F$ is at $\mathrm{p}$-value of 0.000 . This suggests that the overall model is significant and the adjusted $R^{2}$ of the model indicates that $31.7 \%$ of the variance in ROA can be explained by the two operating cash flow ratios. Turning to the significance of each predictor variable, the p-value suggests that both CCDCR and CDCR are important predictors of ROA. However, contrary to the authors' hypothesis $\left(\mathrm{H}_{1}\right)$, the empirical results surprisingly show a significant negative influence of CCDCR on ROA $(\beta=-13.600, p=0.005)$, suggesting that, increasing financial liquidity is associated with decrease in ROA. The higher the level of financial liquidity, the worse the profitability. An implication of this is that the excessive liquidity could cause lost profits although certain level of liquidity is expected which is quite logical. An increase in company's liquidity ratio could be implied as inability of the management to utilize company's assets efficiently. This is consistent with the result of Eljelly (2004). However, as expected, the result of this study indicates a statistically significant and positive influence of CDCR on ROA $(\beta=28.075, p=0.000)$. This result clearly supports the authors' hypothesis $\left(\mathrm{H}_{2}\right)$, indicating 
that, the higher the level of financial flexibility measured by cash debt coverage ratio, the better the profitability as measured by ROA. This is consistent with earlier study of Ayaydin et al. (2014) who found that financial flexibility is an important indicator of performance. An increase in the level of financial flexibility asserts that the company's ability to pay its obligations is improved and the company can still survive without external sources in responding to opportunities and difficulties. However, if the level is too high, according to the finding of Meier et al. (2013), the company would not perform very well and therefore efficiently managing company financial flexibility is needed to avoid losses.

The second regression model with ROE as dependent variable shows the calculated F-statistic is 4.458 and the significant $F$ is at p-value of 0.018 . This result reveals that the overall model is significant and the adjusted $R^{2}$ of the model indicates that $15.1 \%$ of the variance in ROE can be explained by the two operating cash flow ratios. However, turning to the significance of each predictor variable, the result indicates that CCDCR does not predict $\operatorname{ROE}(\beta=-13.029, p=0.099)$. Thus, $\mathrm{H}_{1}$ is not supported with $\mathrm{ROE}$ as dependent variable. This finding was unexpected and suggests that financial liquidity has no important contribution to profitability as measured by ROE. A possible explanation is that company's financial liquidity cannot predict return on equity because it should take into account the contribution of creditors as capital provider on company's profit. ROE measures the rate of income earned on the amount invested by equity investors only. On the other side, as expected, the current study found that CDCR has statistically significant positive influence on ROE $(\beta=30.147$, $p=0.011)$. Hence, $\mathrm{H}_{2}$ is supported with $\mathrm{ROE}$ as dependent variable. A company's level of financial flexibility is considered an important predictor of profitability measured by return on equity. The higher the level of financial flexibility measured by cash debt coverage ratio, the better the profitability. This result supports previous findings of Ayaydin et al. (2014) and Meier et al. (2013) during the Asian crisis. This finding may indicate that the business sectors under study manage their financial flexibility efficiently to avoid losses whilst holding certain level of financial flexibility since Meier et al. (2013) found that firms with very high level of financial flexibility did not perform very well. As part of robustness check, to further detemine the significance of CDCR in explaining ROE, Table 3 shows the simple regression result using CDCR only as the predictor variable. This result indicates that $13.2 \%$ of the variance in ROE can be explained by CDCR and as expected, the higher the level of financial flexibility, the better the profitability measured by ROE.

The third regression model with EPS as dependent variable shows that the calculated F-statistic is 0.968 and the significant $F$ is at p-value of 0.389 . This result indicates that the overall model is not significant. Thus, $\mathrm{H}_{1}$ and $\mathrm{H}_{2}$ are not supported with EPS as dependent variable. This finding is unexpected and suggests that financial liquidity and financial flexibility measured by CCDCR and CDCR are not considered as important factors in predicting EPS as company performance. This is inconsistent with prior empirical evidence (see Ayaydin et al., 2014; Eljelly, 2004; Meier et al., 2013). This inconsistency may be due to the different financial liquidity and financial flexibility measures as well as performance measures used previously. Another possible explanation for this is that the economic conditions and the market/countries used by prior studies are different from this current study. These results therefore need to be interpreted with caution.

Further examination was conducted to check which of the two operating cash flow ratios is relatively more important than the other to predict profitability (see Table 4). The results indicate that CDCR (Std. $\beta=1.152$ ) is more important than CCDCR (Std. $\beta=-0.816$ ) in predicting ROA; CDCR (Std. $\beta=0.809$ ) is more important than CCDCR (Std. $\beta=-0.511$ ) in predicting ROE; and CDCR (Std. $\beta=0.417$ ) is more important than CCDCR (Std. $\beta=-0.274$ ) in predicting EPS. This result may be explained by the fact that CDCR as a measure of 
financial flexibility assesses company's ability to settle its total liabilities using net cash flow from operating activities whereas CCDCR assesses company's ability to settle its current liabilities only.

Table 2

Results of Multiple Regression Analysis for Each Profitability Measure $\left(\mathrm{H}_{1}-\mathrm{H}_{2}\right)$

\begin{tabular}{|c|c|c|c|}
\hline & Return on assets & Return on equity & Earnings per share \\
\hline $\begin{array}{l}\text { Variables (with hypothesized } \\
\text { relationships in parentheses) } \\
\text { (Constant) }\end{array}$ & $\begin{array}{l}\text { Unstandardized } \beta \\
\text { (p-value }^{*} \text { ) } \\
1.833(0.100) \\
\end{array}$ & $\begin{array}{l}\text { Unstandardized } \beta \\
\text { (p-value }^{*} \text { ) } \\
4.130(0.032) \\
\end{array}$ & $\begin{array}{l}\text { Unstandardized } \beta \\
\left(\mathrm{p} \text {-value }{ }^{*}\right) \\
23.561(0.076) \\
\end{array}$ \\
\hline \multicolumn{4}{|l|}{ Hypotheses: } \\
\hline $\mathrm{H}_{1}: \operatorname{CCDCR}(+)$ & $-13.600(0.005)$ & $-13.029(0.099)$ & $-44.676(0.409)$ \\
\hline $\mathrm{H}_{2}: \mathrm{CDCR}(+)$ & $28.075(0.000)$ & $30.147(0.011)$ & $99.569(0.211)$ \\
\hline $\mathrm{R}^{2}=$ & 0.352 & 0.194 & 0.050 \\
\hline Adj. $R^{2}=$ & 0.317 & 0.151 & -0.002 \\
\hline F-value $=$ & 10.065 & 4.458 & 0.968 \\
\hline Prob. $(F)=$ & 0.000 & 0.018 & 0.389 \\
\hline No. of observations $=$ & 40 & 40 & 40 \\
\hline Dependent variable & ROA & ROE & EPS \\
\hline
\end{tabular}

Note. Predictors: $\left(\right.$ constant); $\mathrm{CCDCR}=$ current cash debt coverage ratio; $\mathrm{CDCR}=$ cash debt coverage ratio; ${ }^{*}$ Significant at the 0.05 level.

Table 3

Results of Simple Regression Analysis for Return on Equity $\left(\mathrm{H}_{2}\right)$

\begin{tabular}{ll}
\hline $\begin{array}{l}\text { Variables (with hypothesized } \\
\text { relationships in parentheses) } \\
\text { (Constant) }\end{array}$ & $\begin{array}{l}\text { Return on equity } \\
\text { (p-value* })\end{array}$ \\
\hline Hypotheses: & $4.218(0.032)$ \\
\hline $\mathrm{H}_{2}:$ CDCR $(+)$ & $13.522(0.021)$ \\
$\mathrm{R}^{2}=$ & 0.132 \\
F-value $=$ & 5.768 \\
Prob. $(\mathrm{F})=$ & 0.021 \\
No. of observations $=$ & 40 \\
Dependent variable & $\mathrm{ROE}$ \\
\hline
\end{tabular}

Note. Predictors: (constant); $\mathrm{CDCR}=$ cash debt coverage ratio; ${ }^{*}$ Significant at the 0.05 level.

Table 4

Results of Standardized $\beta$ for Each Profitability Measure $\left(H_{1}-H_{2}\right)$

\begin{tabular}{llll}
\hline & Return on assets & Return on equity & Earnings per share \\
\hline $\begin{array}{l}\text { Variables (with hypothesized } \\
\text { relationships in parentheses) }\end{array}$ & Standardized coefficients $\beta$ & Standardized coefficients $\beta$ & Standardized coefficients $\beta$ \\
\hline Hypotheses: & & & \\
\hline $\mathrm{H}_{1}:$ CCDCR $(+)$ & -0.816 & -0.511 & -0.274 \\
$\mathrm{H}_{2}$ : CDCR $(+)$ & 1.152 & 0.809 & 0.417 \\
No. of observations $=$ & 40 & 40 & 40 \\
Dependent variable & ROA & ROE & EPS \\
\hline
\end{tabular}

Note. $\mathrm{CCDCR}=$ current cash debt coverage ratio; $\mathrm{CDCR}=$ cash debt coverage ratio.

There are a number of limitations to this study. Firstly, the current study used a single nation and single sector, Indonesia's basic industry and chemicals subsector. Secondly, the regression analysis was conducted for 
only one financial year. Despite the limitations, it is felt that the results provide valuable insights into the influence of financial liquidity and financial flexibility measured by cash flow from operating activities ratios on the three profitability indicators.

\section{Conclusions}

The authors present evidence that operating cash flow ratios measured by current cash debt coverage ratio and cash debt coverage ratio can predict company's profitability. This study is motivated by the gap in the literature that examines the importance of cash flow based measures in predicting profitability. Current cash debt coverage ratio measures company's financial liquidity and cash debt coverage ratio measures financial flexibility. Profitability is measured by return on assets, return on equity, and earnings per share. The testable hypotheses pursued in this paper stem from the argument that cash flow information is very important in predicting company performance and cash flows can have incremental value relevance relative to either earnings or fund flows.

Despite convincing arguments that the higher the level of financial liquidity and financial flexibility, the better the profitability, the empirical evidence is mixed. As expected, the results indicate a significant positive influence of cash debt coverage ratio on both return on assets and return on equity. The results reveal that financial flexibility is an important predictor of pofitability. The higher the level of financial flexibility measured by cash debt coverage ratio, the better the profitability measured by return on assets and return on equity. These findings may help us understand that the efficient financial flexibility management is necessary to avoid losses whilst holding certain level of financial flexibility. Thus, These findings are relevant to previous literature on the resolution of the importance of cash flow based measures in predicting profitability. However, one unanticipated finding was that cash debt coverage ratio has no predictive ability on earnings per share.

Contrary to the authors' hypothesis, the empirical results surprisingly show a significant negative influence of current cash debt coverage ratio on return on assets, suggesting that, the higher the level of financial liquidity, the worse the profitability. An implication of this is that the excessive liquidity could cause lost profits indicating the inability of the management to utilize company's assets efficiently. Moreover, the authors' results indicate that current cash debt coverage ratio has no important contribution to return on equity and earnings per share. Further, the findings also suggest that cash debt coverage ratio has more predictive ability relative to current cash debt coverage ratio on profitability. Overall, the evidence highlights the influence of financial liquidity and financial flexibility on profitability as measured by return on assets and return on equity. This study contributes to current understanding of the usefulness of operating cash flow ratios in predicting profitability.

Suggestions for future research are as follows. Other cash flow ratios could be related to other measures of corporate performance. For example, future research could utilize cash interest coverage ratio, capital expenditure ratio, operating cash flow/sales ratio, and free cash flow/operating cash flow ratio as predictor variables with size and leverage as control variables to determine what kind of cash flow ratios could predict operating performance.

\section{References}

Akbar, S., Shah, S. Z. A., \& Stark, A. W. (2011). The value relevance of cash flows, current accruals, and non-current accruals in the UK. International Review of Financial Analysis, 20(5), 311-319. 
Amuzu, M. S. (2010). Cash flow ratio as a measure of performance of listed companies in emerging economies: The Ghana example. Unpublished doctoral dissertation, St. Clements University, Turks and Caicos Islands.

Ayaydin, Ö. A., Florackis, C., \& Ozkan, A. (2014). Financial flexibility, corporate investment and performance: Evidence from financial crises. Review of Quantitative Finance and Accounting, 42(2), 211-250.

Bee, T. S., \& Abdollahi, M. (2013). Corporate failure prediction: Malaysia's emerging market. The International Journal of Finance, 25(4), 7985-8008.

Bhandari, S. B., \& Iyer, R. (2013). Predicting business failure using cash flow statement based measures. Managerial Finance, 39(7), 667-676.

Bhatt, P., \& Sumangala, J. K. (2012). Impact of earnings per share on market value of an equity share: An empirical study in Indian capital market. Journal of Finance, Accounting and Management, 3(2), 1-14.

D'Amato, E. (2010). The top 15 financial ratios. Chatswood, NSW: The Australian Shareholders' Association. Retrieved from http://members.lincolnindicators.com.au/content/filestore/research/top-15-financial-ratios.pdf

de Wet, J. H. V. H., \& du Toit, E. (2007). Return on equity: A popular, but flawed measure of corporate financial performance. South African Journal of Business Management, 38(1), 59-69.

Eljelly, A. M. A. (2004). Liquidity-Profitability tradeoff: An empirical investigation in an emerging market. International Journal of Commerce and Management, 14(2), 48-61.

Eyisi, A. S., \& Okpe, I. I. (2014). The impact of cash flow ratio on corporate performance. Research Journal of Finance and Accounting, 5(6), 149-158.

Frank, B. P., \& James, O. K. (2014). Cashflow and corporate performance: A study of selected food and beverages companies in Nigeria. European Journal of Accounting Auditing and Finance Research, 2(7), 77-87.

Hagel III, J., Brown, J. S., Samoylova, T., \& Lui, M. (2013). Success or struggle: ROA as a true measure of business performance (shift index series report no. 3). Retrieved from http://dupress.com/articles/success-or-struggle-roa-as-a-true-measuryeof-business-performance/

Ibarra, V. C. (2009). Cash flow ratios: Tools for financial analysis. Journal of International Business Research, 8(1), 91-107.

Jerris, S. I. (n.d.). Earnings per share reporting: A movement toward international harmonization. Journal of Applied Research, 14(3), 11-19.

Jooste, L. (2006). Cash flow ratios as a yardstick for evaluating financial performance in African businesses. Managerial Finance, 32(7), 569-576.

Keramidou, I., Mimis, A., Fotinopoulou, A., \& Tassis, C. D. (2013). Exploring the relationship between efficiency and profitability. Benchmarking: An International Journal, 20(5), 647-660.

Khatab, H., Masood, M., Zaman, K., Saleem, S., \& Saeed, B. (2011). Corporate governance and firm performance: A case study of Karachi stock market. International Journal of Trade, Economics and Finance, 2(1), 39-43.

Kieso, D. E., Weygandt, J. J., \& Warfield, T. D. (2011). Intermediate accounting IFRS edition. USA: John Wiley \& Sons, Inc.

Kirkham, R. (2012). Liquidity analysis using cash flow ratios and traditional ratios: The telecommunications sector in Australia. Journal of New Business Ideas \& Trends, 10(1), 1-13.

Meier, I., Bozec, Y., \& Laurin, C. (2013). Financial flexibility and the performance during the recent financial crisis. International Journal of Commerce and Management, 23(2), 79-96.

Mills, J. R., \& Yamamura, J. H. (1998). The power of cash flow ratios. Journal of Accountancy, 186(4), 53-61.

Public Communication Center Ministry of Industry Republic of Indonesia. (2012). Industry facts and figures 2012. Retrieved from http://www.kemenperin.go.id/download/2971

Reeve, J. M., Warren, C. S., \& Duchac, J. (2012). Principles of accounting (24th ed.). China: South Western Cengage Learning.

Rujoub, M. A., Cook, D. M., \& Hay, L. E. (1995). Using cash flow ratios to predict business failures. Journal of Managerial Issues, VII(1), 75-90.

Strong, R. A. (2007). Practical investment management (4th ed.). Canada: Thomson South-Western.

Subramanyam, K. R., \& Wild, J. J. (2009). Financial statement analysis (10th ed.). New York: McGraw-Hill Companies, Inc.

Weygandt, J. J., Kimmel, P. D., \& Kieso, D. E. (2013). Financial accounting IFRS edition (2nd ed.). NJ: John Wiley \& Sons, Inc. 